Article

\title{
Environmental Risk Evaluation and Source Identification of Heavy Metal(loid)s in Agricultural Soil of Shangdan Valley, Northwest China
}

\author{
Sukai Zhuang ${ }^{1,2}$ and Xinwei Lu ${ }^{1, *}$ \\ 1 Department of Environmental Science, School of Geography and Tourism, Shaanxi Normal University, \\ Xi'an 710119, China; zhsukai@snnu.edu.cn \\ 2 College of Chemical Engineering and Modern Materials/Shaanxi Key Laboratory of Comprehensive \\ Utilization of Tailings Resources, Shangluo University, Shangluo 726000, China \\ * Correspondence: luxinwei@snnu.edu.cn or luxinwei88@aliyun.com; Tel.: +86-29-8531-0525
}

Received: 22 June 2020; Accepted: 17 July 2020; Published: 19 July 2020

\begin{abstract}
To understand the environmental quality and heavy metal(loid) pollution of farmlands in Shangdan Valley, the contents of macroelements $(\mathrm{Na}, \mathrm{K}, \mathrm{Si}, \mathrm{Mg}, \mathrm{Ca}, \mathrm{Al}, \mathrm{Fe}, \mathrm{Ti}, \mathrm{P}, \mathrm{S}, \mathrm{Cl}, \mathrm{Br}$ ) and heavy metal(loid)s (Cu, $\mathrm{Pb}, \mathrm{Zn}, \mathrm{Mn}, \mathrm{Ni}, \mathrm{V}, \mathrm{Co}, \mathrm{Cr}, \mathrm{As})$ were surveyed by the $\mathrm{X}$-ray fluorescence method. The pollution degree and ecological risk of the heavy metal(loid)s were judged by the Nemerow synthetic pollution index, geo-accumulation index, and potential ecological risk index, and their sources were identified by the multivariate statistic method. The mean contents of nine heavy metal(loid)s in Shangdan Valley farmland soil exceeded their corresponding reference values. Soils were not contaminated with $\mathrm{As}, \mathrm{Cr}, \mathrm{Mn}$, and $\mathrm{Ni}$ but were slightly contaminated with $\mathrm{Co}, \mathrm{Cu}, \mathrm{Pb}$, $\mathrm{V}$, and $\mathrm{Zn}$. Their comprehensive pollution levels were moderate to serious. The ecological risk index of single heavy metal(loid) decreased in the sequence $\mathrm{As}>\mathrm{Pb}>\mathrm{Co}>\mathrm{Cu}>\mathrm{Ni}>\mathrm{V}>\mathrm{Zn}>\mathrm{Cr}>\mathrm{Mn}$. The source analysis results indicated that $\mathrm{Cu}, \mathrm{Pb}, \mathrm{Zn}$, and As were highly affected by anthropogenic inputs, e.g., metal smelting and agricultural activities, while $\mathrm{Mn}, \mathrm{Ni}, \mathrm{Cr}$, and $\mathrm{V}$ were principally derived from a natural source. As for $\mathrm{Co}$, it was affected by a mixture source of nature, fossil fuel combustion, and fertilizer.
\end{abstract}

Keywords: agricultural soil; heavy metal(loid); ecological risk; source identification; pollution evaluation; multivariate statistical analysis

\section{Introduction}

Soil is one of the most valuable natural resources and the fundamental material of human survival and agricultural production [1]. With the expeditious development of industrialization and urbanization, the condition of soil contamination has become worse [2,3]. Heavy metal(loid)s, a group of metals and metalloids (e.g., As) with potential toxicity [4], are partly responsible for soil pollution and degeneration of environmental quality due to their characteristics of persistence, accumulation, and easy enrichment $[5,6]$. Once heavy metal(loid)s enter the soil where they accumulate beyond the natural purification capacity of them, they will make the physical, chemical, and biological characteristics of the soil changed [7], lead to the loss of soil nutrients and soil degradation, and further result in the reduction of crop production and the quality of agricultural products [8]. The soil polluted by heavy metal(loid)s will also cause air pollution, surface water pollution, groundwater pollution, and other ecological environmental problems [9]. In addition, heavy metal(loid)s in the soil can be easily transferred into the body through direct exposure, such as ingestion, inhalation, and dermal contact [10-12], or through food chain pathways, endangering human health and causing a variety of diseases [13,14]. Some heavy metal(loid)s, e.g., $\mathrm{As}, \mathrm{Cd}, \mathrm{Hg}$, and $\mathrm{Pb}$, will lead to hazardous health problems such as renal insufficiency, 
liver injury, skin cancer, and painful osteoporosis [15-17], while other heavy metal(loid)s, such as Cu, $\mathrm{Mn}, \mathrm{Zn}$, etc., are necessary for the healthy growth of plants or animals but beyond a certain amount will also produce toxicity to organisms $[18,19]$. In recent decades, the accumulation of soil heavy metal(loid)s and the assessment on their ecological-health risk has become a widespread problem and drawn significant research attention worldwide [20-24]. A lot of research has been carried out on spatial distribution $[25,26]$, migration process $[27,28]$, source analysis $[23,29,30]$, ecological risk assessment [20,22,31], and remediation [32,33] of heavy metal(loid)s in the soil.

Over the past few decades, during the process of industrialization and urbanization in China, many farmlands have been converted into lands of industry, transportation, or urbanization. At the same time, the change of land-use type also leads to the decline of soil environmental quality in some areas. The Shangdan Valley selected in this study is an example of a land-use type changing from agricultural land to industrial land. In this research, the agricultural soil of the Shangdan Valley was investigated, and the contents of major elements and heavy metal(loid)s in farmland soil were determined. The environmental risks of heavy metal(loid)s were evaluated by the Nemerow synthetic pollution index (NSPI), geo-accumulation index $\left(I_{\text {geo }}\right)$, and potential ecological risk index (PERI), and the sources of heavy metal(loid)s in farmland soil were analyzed by multivariate statistics. It is expected to offer scientific evidence for pollution interruption of farmland soil, ecological environment protection, and the healthy life of residents through this study.

\section{Materials and Methods}

\subsection{Background of Study Area}

Shangdan Basin is situated in the southeast of Shaanxi Province, northwest of China, and between the longitudes of $109^{\circ} 54^{\prime}-110^{\circ} 18^{\prime} \mathrm{E}$ and latitudes of $33^{\circ} 37^{\prime}-33^{\circ} 56^{\prime} \mathrm{N}$. Danjiang river, a secondary tributary of the Yangtze River, traverses the basin from northwest to southeast. The study area, a typical valley basin, is about $60-\mathrm{km}$ long and $5-\mathrm{km}$ wide. It is the water source area of the Mid-route of South-North Water Transfer Project. Shangdan Basin with four distinct seasons is a transitional monsoon climate area of the north subtropical and warm temperate zone, where the annual average temperature is about $13{ }^{\circ} \mathrm{C}$. In addition, the yearly precipitation is $710-930 \mathrm{~mm}$ with an uneven seasonal distribution of precipitation, especially from July to September, accounting for more than $60 \%$ of the annual precipitation. Soils in the Shangdan Basin are classified as Luvisols according to the World Reference Base for Soil Resources (WRB), and the type of land use mainly belongs to farmland. Wheat and maize are the dominant cereal crops in this area and the crops are irrigated by water from the Danjiang River and its tributaries. From ancient times until now, the Shangdan Basin has always been the main grain-producing area and residential area of Shangluo. In 2009, a provincial industrial park, Shangdan Circular Industrial Economic Park, was established in the Shangdan Basin. With the establishment of the industrial park, some new enterprises such as solar photovoltaic, new energy vehicles, modern materials, and medicine have been built or have been under construction one after another, and some agricultural land in the Shangdan Basin has been gradually developed into industrial land as well. Up to now, the Shangdan Basin has formed a land-use pattern in which farmland is dominant with a mixed industrial land. Therefore, the investigation and evaluation of heavy metal(loid) content in the farmland soil of the Shangdan Basin can help us to understand the current heavy metal(loid) content in the farmland, judge the degree of anthropogenic influence, and provide the basic information for the evaluation of the impact of agriculture and industry on the farmland quality in the future.

\subsection{Sampling and Analytical Methods}

The investigated soil type of farmlands in the Shangdan Basin is Luvisols. Combined with the specific location and land-use status of the study area, 38 topsoil samples were collected from farmland. Global Positioning System (GPS) was used in the process of positioning, and the information around 
the sampling point was recorded. Topsoil samples $(0-20 \mathrm{~cm})$ were taken directly with a nonmetallic shovel during sampling. The root system, straw, stone, and other debris were picked out. A composite sample at each sampling site was obtained by mixing 3-5 subsamples. Samples were kept in a nylon sample bag, labeled and transported to the laboratory. The sampling location and distribution are shown in Figure S1 (Supplementary Materials).

The soil samples were spread out on paper and placed on a well-ventilated, clean, and dust-free laboratory bench to dry naturally. Then the air-dried sample was crushed with a wooden bar on a clean surface and the sundries were picked out again. Agate mortar and pestle were used to grind the sample to $<75 \mu \mathrm{m}$. To avoid possible cross-contamination, all processing was operated without contact with any metal. Four grams of treated soil and about $2 \mathrm{~g}$ of boric acid were pressed with a molding machine to form a circular plate sample to be tested [34]. The element contents in agricultural soils were detected with X-ray fluorescence spectrometry (XRF, Brucker S8, Germany). The detail pre-treatment method of soil sample and experimental method were cited from the literature $[35,36]$. National standard material samples (Chinese standard soil samples GSS6 and GSS8, purchased from the Center of National Standard Reference Material of China) and parallel samples were adopted for quality assurance and control. The relative error between the detected value and reference value of elements in the standard sample was less than $10 \%$, and that of the duplicate sample was less than $5 \%$.

\subsection{Pollution and Ecological Risk Assessment Methods}

\subsubsection{Single Pollution Index and Nemerow Synthetic Pollution Index}

Single pollution index $\left(P_{i}\right)$ is often applied to assess heavy metal(loid) contamination of soil, which can judge the main pollution factor in the environment and reflect the pollution degree of a pollutant $[37,38]$. Meanwhile, the result of $P_{i}$ is the basis of the Nemerow synthetic pollution index. The calculation method of $P_{i}$ is shown in the following formula:

$$
P_{i}=\frac{C_{i}}{S_{i}}
$$

In Formula (1), $C_{i}$ is the actual determined result of $i$ element, and $S_{i}$ is the reference value of $i$ element [39]. Soil pollution can be differentiated as low $\left(P_{i} \leq 1\right)$, middle $\left(1<P_{i} \leq 3\right)$, and high $\left(P_{i}>3\right)$ [37].

$P_{i}$ cannot reflect the comprehensive pollution level of heavy metal(loid)s in the soil as a whole, while heavy metal(loid) contamination in agricultural soil is a kind of compound pollution caused by the simultaneous action of multiple heavy metal(loid)s. As a widely used comprehensive evaluation method, the Nemerow synthetic pollution index (NSPI) can comprehensively reflect the contamination degree of heavy metal(loid)s in the environment [40,41]. The calculation method of NSPI was calculated according to Formula (2):

$$
N S P I=\sqrt{\frac{P_{\text {iave }}^{2}+P_{\text {imax }}^{2}}{2}}
$$

where $P_{\text {imax }}$ is the highest value of $P_{i}$ of all heavy metal(loid)s in a sample, and $P_{\text {iave }}$ is the mean value of $P_{i}$ of all heavy metal(loid)s in a sample. The soil grading standards of $P_{i}$ and NSPI are shown in Table S1 (Supplementary Materials).

\subsubsection{Geo-Accumulation Index Method}

The geo-accumulation index ( $\left.I_{\text {geo }}\right)$, established by Müller [42], was originally used to study the quantitative index of heavy metal(loid) pollution in sediment. Now, it has been extensively applied in the evaluation of toxic element pollution in sediments [43], soils [44], dust [45,46], and other environmental media. In addition to considering the natural variation of heavy metal(loid) distribution, $I_{\text {geo }}$ also considers the influence of anthropogenic pollution factors, which is the main parameter to 
distinguish anthropogenic activity changes. In this study, $I_{\text {geo }}$ was adopted to assess the level of heavy metal(loid) contamination in the farmland soil of the Shangdan Valley. The evaluation formula is expressed as follows:

$$
I_{\text {geo }}=\log _{2} \frac{C_{i}}{1.5 \times B_{i}}
$$

where $C_{i}$ is the content of heavy metal(loid) $i$ in soil, and $B_{i}$ is the reference value of heavy metal(loid) $i$. In this work, Shaanxi soil background value was taken as the reference. The pollution classification based on the $I_{\text {geo }}$ value is listed in Table S2 (Supplementary Materials).

\subsubsection{Potential Ecological Risk Index}

The Hankånson potential ecological risk index (PERI) method combines the environmental effects of toxic elements with toxicology to evaluate their potential ecological hazards [47]. This method combines the concentration of toxic elements with their ecological effects, environmental effects, and toxicological properties. It is widely used in ecological risk assessment at present [48-51]. The calculation formula is as follows:

$$
\text { PERI }=\sum_{i=1}^{n} E_{r}^{i}=\sum_{i=1}^{n} T_{r}^{i} \times C_{r}^{i}=\sum_{i=1}^{n} T_{r}^{i} \times \frac{C_{s}^{i}}{C_{n}^{i}}
$$

In Formula (4), $C_{s}{ }^{i}$ is the content of heavy metal(loid) $i$ in soil; $C_{n}{ }^{i}$ is the reference value of heavy metal(loid) $i$ [39]; $C_{r}{ }^{i}$ is the pollution index of heavy metal(loid) $i ; T_{r}{ }^{i}$ is the toxic coefficient of heavy metal(loid) $i$, viz. $\mathrm{As}=10, \mathrm{Co}=\mathrm{Cu}=\mathrm{Ni}=\mathrm{Pb}=5, \mathrm{Mn}=\mathrm{Zn}=1, \mathrm{Cr}=\mathrm{V}=2$ [51,52]; $E_{r}{ }^{i}$ is the potential ecological risk factor of heavy metal(loid) $i$; and PERI is the overall potential ecological risk of all heavy metal(loid)s. $E_{r}{ }^{i}$ and PERI classification criteria are listed in Table S3 (Supplementary Materials).

\subsection{Data Analysis}

Descriptive statistical parameters were reckoned for elements determined in agricultural soil. Pearson correlation analysis, cluster analysis (CA), and principal component analysis (PCA) were employed to determine the possible sources of heavy metal(loid)s. All the statistical analyses for the data were executed by using the software package SPSS 19.0 (IBM Company, Chicago, USA) and Origin Pro 8.0 (OriginLab Company, Northampton, USA). The SPSS software offers advanced statistical analysis, a vast library of machine leaning algorithms, text analysis, open source extensibility, integration with big data and seamless deployment into application. Origin Pro is a professional data analysis and graphing software.

\section{Results and Discussion}

\subsection{Macroelement Content}

The descriptive statistics of macroelement concentrations in the agricultural soil of the Shangdan Valley and the background values of Shaanxi soil $[39,53]$ are listed in Table 1 . Compared with the background values of Shaanxi soil, it can be found that the mean contents of $\mathrm{Na}$ and $\mathrm{Ca}$ were lower than and the mean contents of other major elements were similar to or slightly higher than their corresponding background values.

The coefficient of variation $(\mathrm{CV})$ can reveal the spatial variation of the element content. Large CV value means high variability, and small $\mathrm{CV}$ value means low variability [36]. Table 1 shows that the $\mathrm{CV}$ values of $\mathrm{Ca}, \mathrm{S}, \mathrm{Cl}, \mathrm{Br}$, and $\mathrm{P}$ were $72.0 \%, 60.3 \%, 41.4 \%, 37.3 \%$, and $33.3 \%$, respectively, indicating obviously spatial dispersion and possible human disturbance.

The kurtosis values of the analyzed macroelements, except for $\mathrm{K}, \mathrm{Mg}$, $\mathrm{Fe}$, and $\mathrm{Br}$, were larger than zero, indicating that the distributions of these elements were steeper than normal [54]. The skewness 
values of $\mathrm{S}, \mathrm{Cl}$, and $\mathrm{Ca}$ were larger than unity, indicating that these elements positively skewed towards the lower concentration $[54,55]$.

Table 1. Descriptive statistics of macroelement concentration (\% for $\mathrm{Na}, \mathrm{K}, \mathrm{Si}, \mathrm{Mg}, \mathrm{Ca}, \mathrm{Al}, \mathrm{Fe}$, and $\mathrm{Ti}$; $\mathrm{mg} \mathrm{kg}^{-1}$ for $\mathrm{P}, \mathrm{S}, \mathrm{Cl}$, and $\mathrm{Br}$ ) in the agricultural soil of the Shangdan Valley.

\begin{tabular}{cccccccc}
\hline Elements & Mean & Range & SD & CV (\%) & Kurtosis & Skewness & $\begin{array}{c}\text { Background } \\
\text { Value [39] }\end{array}$ \\
\hline $\mathrm{Na}$ & 0.9 & $0.5-1.2$ & 0.2 & 17.0 & 0.9 & 0.1 & 1.2 \\
$\mathrm{~K}$ & 2.1 & $1.9-2.4$ & 0.1 & 5.6 & -0.1 & 0.4 & 1.9 \\
$\mathrm{Si}$ & 29.9 & $25.9-31.4$ & 1.2 & 4.1 & 2.8 & -1.6 & $27.4^{\mathrm{a}}$ \\
$\mathrm{Mg}$ & 1.2 & $1.0-1.6$ & 0.2 & 11.9 & -0.1 & 0.6 & 1.0 \\
$\mathrm{Ca}$ & 1.6 & $0.7-5.8$ & 1.1 & 72.0 & 4.9 & 2.2 & 2.9 \\
$\mathrm{Al}$ & 7.1 & $2.9-7.9$ & 1.0 & 13.6 & 11.1 & -3.2 & 6.8 \\
$\mathrm{Fe}$ & 3.8 & $3.1-4.4$ & 0.3 & 7.8 & -0.4 & -0.4 & 3.2 \\
$\mathrm{Ti}$ & 0.4 & $0.4-0.5$ & 0.03 & 5.7 & 0.9 & -0.4 & 0.4 \\
$\mathrm{P}$ & 906.4 & $468.0-1907.0$ & 302.3 & 33.3 & 1.6 & 0.9 & $721^{\mathrm{a}}$ \\
$\mathrm{S}$ & 233.5 & $115.0-1000.0$ & 140.8 & 60.3 & 24.8 & 4.6 & $184^{\mathrm{a}}$ \\
$\mathrm{Cl}$ & 70.9 & $32.0-192.0$ & 29.4 & 41.4 & 7.5 & 2.4 & $68^{\mathrm{a}}$ \\
$\mathrm{Br}$ & 2.2 & $0.8-3.9$ & 0.8 & 37.3 & -0.5 & 0.5 & 2.1 \\
\hline
\end{tabular}

Notes: SD: standard deviation; CV: coefficient of variance; ${ }^{\text {a }}$ Cheng et al. [53].

\subsection{Heavy Metal(loid) Contents}

The descriptive statistics of heavy metal(loid) contents in the agricultural soil of the Shangdan Valley are listed in Table 2. The mean concentrations of $\mathrm{As}, \mathrm{Co}, \mathrm{Cr}, \mathrm{Cu}, \mathrm{Mn}, \mathrm{Ni}, \mathrm{Pb}, \mathrm{V}$, and $\mathrm{Zn}$ in the agricultural soil of the Shangdan Valley were respectively 1.28, 1.73, 1.26, 1.72, 1.42, 1.27, 1.87, 1.60, and 3.08 times the background values of Shaanxi soil [39]. It indicates that these heavy metal(loid)s had a certain degree of accumulation in the agricultural soil of the Shangdan Valley, especially for $\mathrm{Zn}$, which was 1.16-44.21 times the background value. Combined with Figure S1 and Table S4, it can be found that samples with high zinc content, such as S5, S7, S9, S36, and S37, were clustered at the locations. Taken the results of the field investigation into account, these sample points were located near a zinc smelter. It indicated that the point source contamination of soil zinc element was obvious, which mainly comes from the atmospheric deposition during zinc smelting or the dust generated during the transportation of raw materials and products. The sample points with higher contents of $\mathrm{As}, \mathrm{Cu}$, and $\mathrm{Pb}$ were similar to that of $\mathrm{Zn}$, indicating that their sources may be similar. From Table $\mathrm{S} 4$, the highest contents of element $\mathrm{As}, \mathrm{Cu}, \mathrm{Mn}, \mathrm{Pb}$, and $\mathrm{Zn}$ derived from the same sampling site (S5), which was near a zinc plant, and the concentrations of $\mathrm{As}, \mathrm{Cu}, \mathrm{Mn}, \mathrm{Pb}$, and $\mathrm{Zn}$ in sample site $\mathrm{S} 5$ were $3.61,6.74,2.05,15.03$, and 44.21 times the reference value.

Table 2. Descriptive statistics of heavy metal(loid) concentrations $\left(\mathrm{mg} \mathrm{kg}^{-1}\right)$ in the agricultural soil of the Shangdan Valley.

\begin{tabular}{ccccccccc}
\hline Elements & Max & Min & Mean & SD & CV(\%) & Kurtosis & Skewness & $\begin{array}{c}\text { Background } \\
\text { Value [39] }\end{array}$ \\
\hline $\mathrm{As}$ & 40.1 & 5.4 & 14.2 & 5.5 & 38.6 & 13.1 & 2.8 & 11.1 \\
$\mathrm{Co}$ & 28.0 & 15.2 & 18.3 & 2.4 & 13.1 & 5.9 & 1.9 & 10.6 \\
$\mathrm{Cr}$ & 98.3 & 63.0 & 78.9 & 7.0 & 8.9 & 1.5 & 0.3 & 62.5 \\
$\mathrm{Cu}$ & 114.2 & 27.8 & 36.7 & 18.4 & 49.9 & 34.0 & 5.7 & 21.4 \\
$\mathrm{Mn}$ & 1141.1 & 616.9 & 789.2 & 110.4 & 14.0 & 3.6 & 1.3 & 557.0 \\
$\mathrm{Ni}$ & 43.4 & 39.3 & 36.5 & 3.6 & 9.9 & -0.5 & -0.2 & 28.8 \\
$\mathrm{~Pb}$ & 321.7 & 20.0 & 39.9 & 47.4 & 118.4 & 36.5 & 6.0 & 21.4 \\
$\mathrm{~V}$ & 117.9 & 86.2 & 107.1 & 9.8 & 9.1 & 2.4 & 0.3 & 66.9 \\
$\mathrm{Zn}$ & 3068.4 & 80.4 & 214.0 & 482.9 & 225.6 & 35.6 & 5.9 & 69.4 \\
\hline
\end{tabular}

Notes: SD: standard deviation; CV: coefficient of variance. 
The highest contents of Co and V also came from the same sampling point, which was S38, located at the north edge of the Shangdan Basin, and the highest content of Co and V were 2.64 and 2.08 times the reference value, separately. The highest concentrations of $\mathrm{Cr}\left(98.3 \mathrm{mg} \mathrm{kg}^{-1}\right)$ and $\mathrm{Ni}\left(43.4 \mathrm{mg} \mathrm{kg}^{-1}\right)$ were found in samples S12 and S16, respectively, and they were slightly higher than their corresponding reference values.

Table 2 shows that the $\mathrm{CV}$ order of the nine heavy metal(loid)s from large to small was $\mathrm{Zn}>\mathrm{Pb}>$ $\mathrm{Cu}>\mathrm{As}>\mathrm{Mn}>\mathrm{Co}>\mathrm{Ni}>\mathrm{V}>\mathrm{Cr}$. The $\mathrm{CV}$ values of $\mathrm{Zn}$ and $\mathrm{Pb}$ were significantly larger than those of other elements, reaching $225.6 \%$ and $118.4 \%$, respectively. The $\mathrm{CV}$ values of $\mathrm{Cu}$ and As were also high, which were $49.9 \%$ and $38.6 \%$, respectively. The results indicated that these four elements, especially $\mathrm{Zn}$ and $\mathrm{Pb}$, were not evenly distributed in the agricultural soil and were significantly influenced by anthropogenic activities. On the contrary, the CV values of the other five elements $\mathrm{Mn}, \mathrm{Co}, \mathrm{Ni}, \mathrm{V}$, and $\mathrm{Cr}$ were small, and the values of which were $14.0 \%, 13.1 \%, 9.9 \%, 9.1 \%$, and $8.9 \%$, respectively, indicating that they were less affected by human activities.

The skewness values of $\mathrm{As}, \mathrm{Co}, \mathrm{Cu}, \mathrm{Mn}, \mathrm{Pb}$, and $\mathrm{Zn}$ were greater than unity, showing that the concentrations of these heavy metal(loid)s in the agricultural soil of the Shangdan Valley positively skewed towards lower concentrations [54,55]. The kurtosis values of all heavy metal(loid)s, except for $\mathrm{Ni}$, were higher than zero, which indicates that the distributions of these heavy metal(loid)s were steeper than normal [54].

\subsection{Pollution Level of Heavy Metal(loid)s}

The assessment results of the single pollution index are shown in Table S4. The $P_{i}$ values of heavy metal(loid)s analyzed in all samples, except for As in 11 samples $(28.9 \%)$ and $\mathrm{Pb}$ in 1 sample $(2.6 \%)$, were greater than unity, indicating that these heavy metal(loid)s have accumulated to a certain extent in the farmland soil of the Shangdan Valley. Most of the determined heavy metal(loid)s were at middle pollution level, except for zinc with a mean $P_{i}$ of 3.08, presenting a high pollution level. The reason why the average $P_{i}$ of $\mathrm{Zn}$ was so large is that there was a sample (S5) with a $P_{i}$ as high as 44.21. Table $\mathrm{S} 4$ shows that $\mathrm{As}, \mathrm{Cu}$, and $\mathrm{Pb}$ had one sample (S5) and $\mathrm{Zn}$ had five samples (S5, S7, S9, S36, S37), presenting a high pollution level. In terms of the field study, these sample sites were all distributed around a zinc smelter. Therefore it can be speculated that the pollution of these heavy metal(loid)s in agricultural soil was mainly caused by smelting activities.

The NSPI values of the heavy metal(loid)s in the agricultural soil ranged from 1.96 to 45.05 with an average of 3.79. The NSPI evaluation results (Table S4) indicate that the heavy metal(loid) comprehensive pollution degrees in most samples (28 samples, $73.7 \%$ ) were moderate, while in some samples ( 7 samples, $18.4 \%$ ) they were severe, and in a small part of the samples ( 3 samples, $7.9 \%$ ) they were slight.

The $I_{\text {geo }}$ evaluation results are shown in Figure 1 and Table S5. The average $I_{\text {geo }}$ values decreased in the order of $\mathrm{Zn}(0.37 \pm 0.94)>\mathrm{Co}(0.19 \pm 0.18)>\mathrm{Cu}(0.12 \pm 0.38)>\mathrm{V}(0.09 \pm 0.13)>\mathrm{Pb}(0.07 \pm 0.60)>$ $\mathrm{Mn}(-0.09 \pm 0.19)>\mathrm{Ni}(-0.25 \pm 0.15)=\mathrm{Cr}(-0.25 \pm 0.13)>\mathrm{As}(-0.31 \pm 0.48)$. It indicated that $\mathrm{Zn}, \mathrm{Co}, \mathrm{Cu}$, $\mathrm{V}$, and $\mathrm{Pb}$ were slightly polluted, and $\mathrm{As}, \mathrm{Cr}, \mathrm{Mn}$, and $\mathrm{Ni}$ were unpolluted as a whole. Table S5 shows that the $I_{\text {geo }}$ values of As in most samples (30 samples) were less than 0 , presenting an unpolluted level. The $I_{\text {geo }}$ values of As in 7 samples were between 0 and 1, corresponding to a slightly polluted level, and in 1 sample (S5) it was at a moderately polluted level. The $I_{\text {geo }}$ values of Co ranged from -0.06 to 0.82 , suggesting that the agricultural soil in the Shangdan Valley was unpolluted (4 samples) to slightly polluted (34 samples) by Co. Most of the $I_{\text {geo }}$ values of $\mathrm{Cr}$ were $<0$, indicating no pollution, except for two $I_{\text {geo }}$ values, viz. 0.01 (S15) and 0.07 (S12), which were slightly $>0$, corresponding to a slightly polluted level. Copper in most samples was unpolluted to slightly polluted, with the exception of sample S5 $\left(I_{\text {geo }}=6.74\right)$ which was extremely polluted. The $I_{\text {geo }}$ of Mn varied from -0.44 to 0.43 , corresponding to unpolluted ( 30 samples) to slightly polluted ( 8 samples). The $I_{\text {geo }}$ of $\mathrm{Ni}$ in all soil samples was $<0$, indicating an unpolluted level. The $I_{\text {geo }}$ values of $\mathrm{Pb}$ in most samples were unpolluted (23 samples) to slightly polluted (14 samples), except for one sample (S5, I geo $_{2}=3.33$ ) which 
was severely polluted. The $I_{\text {geo }}$ values of $\mathrm{V}$ in $21.1 \%$ of the samples was $<0$, presenting an unpolluted level, while in $78.9 \%$ it was between 0 and 1, corresponding to a slightly unpolluted level. Zinc had a large pollution variation in the agricultural soils from the Shangdan Valley, viz. unpolluted to severely extremely polluted.

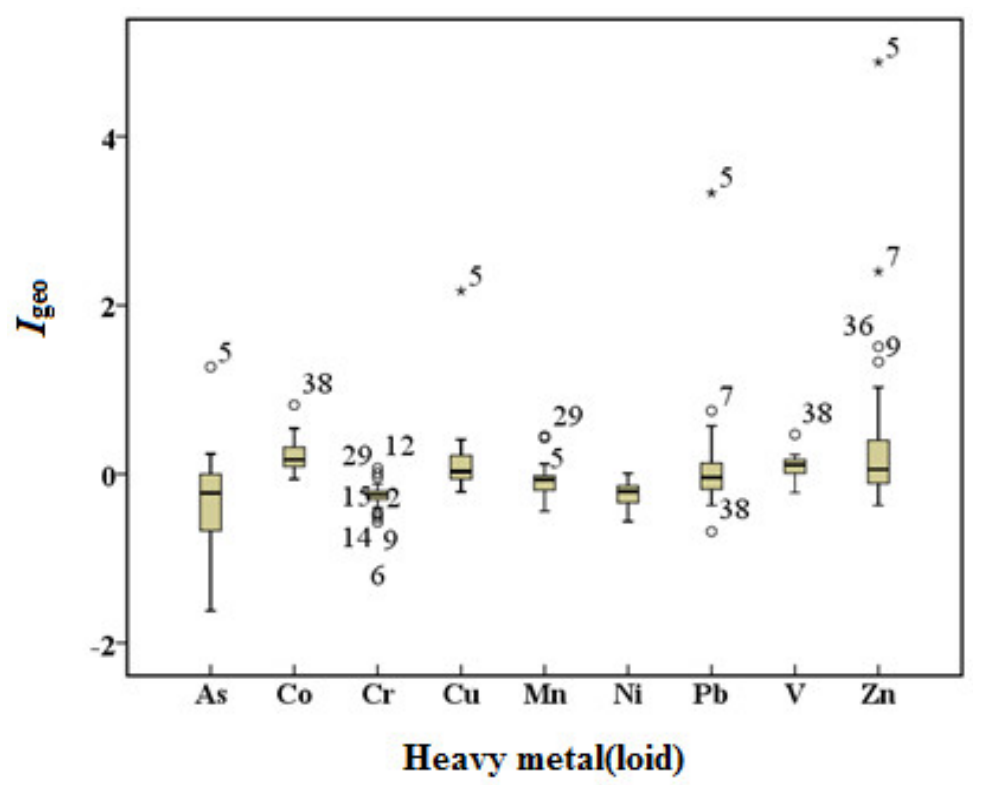

Figure 1. Box-plots of $I_{\text {geo }}$ for heavy metal(loid)s in the agricultural soil of the Shangdan Valley (numbers in the figure represent the sites of samples).

Figure 1 shows that the maximum $I_{\text {geo }}$ values of $\mathrm{As}, \mathrm{Cu}, \mathrm{Pb}$, and $\mathrm{Zn}$ appeared at the same sampling site (S5), which was near a zinc smelter. In addition, in other sampling sites around the zinc smelter (S7, S9, S36, S37), the Igeo values of Zn were also larger (>1), compared to the other sampling sites. The aforementioned results indicate that the agricultural soils around the zinc smelter were contaminated by $\mathrm{As}, \mathrm{Cu}, \mathrm{Pb}$, and especially $\mathrm{Zn}$.

\subsection{Ecological Risk Level of Heavy Metal(loid)s}

The results of $E_{r}{ }^{i}$ and PERI are shown in Table S6. The average $E_{r}{ }^{i}$ value of the heavy metal(loid)s analyzed in the agricultural soil of the Shangdan Valley differed from large to small in the sequence: $\mathrm{As}>\mathrm{Pb}>\mathrm{Co}>\mathrm{Cu}>\mathrm{Ni}>\mathrm{V}>\mathrm{Zn}>\mathrm{Cr}>\mathrm{Mn}$. The $E_{r}{ }^{i}$ value of $\mathrm{As}, \mathrm{Co}, \mathrm{Cr}, \mathrm{Cu}, \mathrm{Mn}, \mathrm{Ni}, \mathrm{Pb}, \mathrm{V}$, and $\mathrm{Zn}$ was in a range of 4.86-36.13, 7.17-13.21, 2.02-3.15, 6.50-33.69, 1.11-2.05, 5.09-7.53, 4.67-75.16, 2.58-4.16, and 1.16-44.21 with an average of $12.80,8.66,2.52,8.59,1.42,6.35,9.35,3.20$, and 3.08, respectively. The $E_{r}{ }^{i}$ values of $\mathrm{Co}, \mathrm{Cr}, \mathrm{Mn}, \mathrm{Ni}$, and $\mathrm{V}$ in all samples were $<15$, indicating that these heavy metal(loid)s possessed low ecological risk in the farmland soil of the Shangdan Valley. The ecological risks of $\mathrm{Cu}, \mathrm{Pb}$, and $\mathrm{Zn}$ in all soil samples, except for soil sample S5, and As in $76.3 \%$ of the samples were low. The soil sample $\mathrm{S} 5$ had the maximum $E_{r}{ }^{i}$ values for $\mathrm{Cu}$ (33.69), As (36.13), $\mathrm{Zn}$ (44.21), and $\mathrm{Pb}$ (75.16), indicating that the ecological risks of $\mathrm{Cu}, \mathrm{As}$, and $\mathrm{Zn}$ in soil sample S5 were considerable, and the ecological risk of $\mathrm{Pb}$ in soil sample $\mathrm{S} 5$ was high. The PERI values of heavy metal(loid)s in the agricultural soil were determined to be in a range from 44.31 to 213.57 with the mean of 55.97. The mean PERI and the PERI values in $57.9 \%$ of the samples were between 50 and 100 , showing a moderate ecological risk. While the PERI values in $39.5 \%$ of the samples were $<50$, indicating a low ecological risk. The overall PERI of the heavy metal(loid)s in soil sample S5 was high.

Figure 2 shows that As was the largest contributor (22.9\%) to PERI, then followed by $\mathrm{Pb}(16.7 \%)$, $\mathrm{Co}(15.5 \%), \mathrm{Cu}(15.3 \%)$, and $\mathrm{Ni}(11.3 \%)$. The contribution rates of other heavy metal(loid)s to PERI were relatively smaller, viz. the contributors of $\mathrm{V}, \mathrm{Zn}, \mathrm{Cr}$, and $\mathrm{Mn}$ to PERI were $5.7 \%, 5.5 \%, 4.5 \%$, and $2.5 \%$, respectively. This indicated that the contribution rate of heavy metal(loid)s to PERI was not 
only related to their contents but also related to their toxicity response factors. Compared with the other eight heavy metal(loid)s, although the content of As in the agricultural soil was relatively low, its ecological risk was the highest, which should receive more attention.

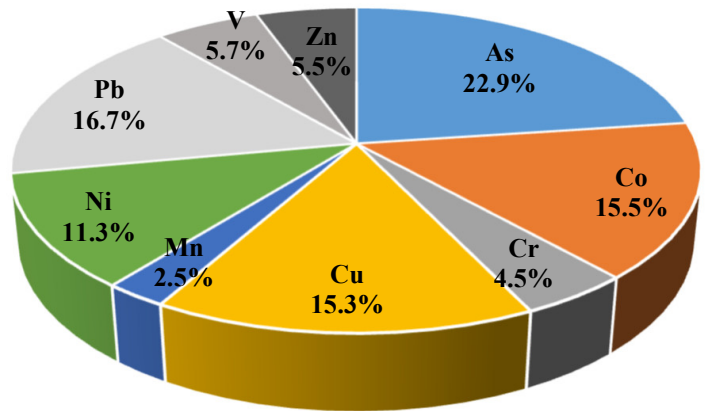

Figure 2. The contribution of heavy metal(loid)s to the potential ecological risk.

\subsection{Multivariate Statistical Analysis Results}

\subsubsection{Pearson's Correlation Analysis Results}

Correlation analysis is widely used in the analysis of soil pollutant sources [56]. By studying the correlation between heavy metal(loid)s in a certain area, it can be inferred whether there are common behaviors and sources of heavy metal(loid)s in the agricultural soil of the research area. Pearson's correlation coefficients for heavy metal(loid)s in the agricultural soil of the Shangdan Valley are summarized in Table 3. Table 3 shows that high correlations existed among $\mathrm{As}, \mathrm{Cu}, \mathrm{Pb}$, and $\mathrm{Zn}$ $(r>0.7 ; p<0.01)$, indicating that these elements in the soils of the Shangdan Valley derived from similar sources. Significantly moderate to strong positive correlations $(p<0.01)$ were observed among the metal pairs of $\mathrm{Cr}-\mathrm{Mn}(0.560), \mathrm{Cr}-\mathrm{V}(0.738), \mathrm{Cr}-\mathrm{Ni}(0.764), \mathrm{Mn}-\mathrm{Ni}(0.494), \mathrm{Mn}-\mathrm{V}(0.441)$, and Ni-V(0.594). Co only had good correlation with $\mathrm{Cr}$ and $\mathrm{V}$, and the correlation coefficients were 0.473 and 0.543 $(p<0.01)$, respectively.

Table 3. Pearson's correlation matrix for heavy metal(loid)s in the agricultural soil of the Shangdan Valley.

\begin{tabular}{cccccccccc}
\hline Elements & $\mathbf{A s}$ & $\mathbf{C o}$ & $\mathbf{C r}$ & $\mathbf{C u}$ & $\mathbf{M n}$ & $\mathbf{N i}$ & $\mathbf{P b}$ & $\mathbf{V}$ & $\mathbf{Z n}$ \\
\hline $\mathrm{As}$ & 1 & -0.025 & 0.297 & $0.741^{* *}$ & $0.606^{* *}$ & $0.509^{* *}$ & $0.781^{* *}$ & 0.124 & $0.796^{* *}$ \\
$\mathrm{Co}$ & 0.880 & 1 & $0.473^{* *}$ & 0.255 & 0.200 & 0.198 & 0.141 & $0.540^{* *}$ & 0.162 \\
$\mathrm{Cr}$ & 0.071 & 0.003 & 1 & 0.162 & $0.560^{* *}$ & $0.764^{* *}$ & 0.075 & $0.738^{* *}$ & 0.101 \\
$\mathrm{Cu}$ & 0.000 & 0.122 & 0.331 & 1 & $0.476^{* *}$ & 0.095 & $0.973^{* *}$ & 0.095 & $0.970^{* *}$ \\
$\mathrm{Mn}$ & 0.000 & 0.228 & 0.000 & 0.003 & 1 & $0.494^{* *}$ & $0.500^{* *}$ & $0.441^{* *}$ & $0.516^{* *}$ \\
$\mathrm{Ni}$ & 0.001 & 0.233 & 0.000 & 0.569 & 0.002 & 1 & 0.028 & $0.549^{* *}$ & 0.060 \\
$\mathrm{~Pb}$ & 0.000 & 0.399 & 0.656 & 0.000 & 0.001 & 0.865 & 1 & -0.002 & $0.996^{* *}$ \\
$\mathrm{~V}$ & 0.459 & 0.000 & 0.000 & 0.569 & 0.006 & 0.000 & 0.992 & 1 & 0.037 \\
$\mathrm{Zn}$ & 0.000 & 0.333 & 0.548 & 0.000 & 0.001 & 0.719 & 0.000 & 0.827 & 1 \\
\hline
\end{tabular}

The right upper part is correlations; the left lower part is the significance level. ${ }^{* *}$ Correlation is significant at $p<0.01$ (two-tailed).

\subsubsection{Principal Component Analysis Results}

PCA is a powerful and useful tool used to collect and extract the information of heavy metal(loid)s in soil or dust to obtain the source of heavy metal(loid)s [54,55,57]. It can be used to analyze the combined characteristics of the observed variables. In addition, principal component analysis can effectively eliminate the spatial diversity of sample variables and facilitate the extraction of information among sample variables. The Kaiser-Meyer-Olkin (KMO) score (0.721) and Bartlett's sphericity test value $(p=0)$ showed that the data set was suitable for PCA. The results of the PCA of heavy metal(loid)s are shown in Table 4. 
Table 4. Rotated component matrix for data of soil in the Shangdan Valley.

\begin{tabular}{ccccc}
\hline Elements & PC1 & PC2 & PC3 & Communality \\
\hline $\mathrm{As}$ & 0.811 & 0.445 & -0.257 & 0.922 \\
$\mathrm{Co}$ & 0.109 & 0.172 & 0.933 & 0.911 \\
$\mathrm{Cr}$ & 0.048 & 0.856 & 0.368 & 0.870 \\
$\mathrm{Cu}$ & 0.964 & 0.039 & 0.175 & 0.962 \\
$\mathrm{Mn}$ & 0.517 & 0.643 & 0.045 & 0.684 \\
$\mathrm{Ni}$ & 0.041 & 0.938 & -0.031 & 0.883 \\
$\mathrm{~Pb}$ & 0.995 & -0.006 & 0.054 & 0.993 \\
$\mathrm{~V}$ & -0.041 & 0.705 & 0.557 & 0.808 \\
$\mathrm{Zn}$ & 0.992 & 0.026 & 0.069 & 0.990 \\
Eigenvalue & 3.847 & 2.753 & 1.423 & \\
\% of Total explained variance & 42.750 & 30.584 & 15.809 & \\
\% of cumulative & 42.750 & 73.334 & 89.143 & \\
\hline
\end{tabular}

Three principal components with eigenvalues larger than unity were extracted. The cumulative contribution rate of the three principal component factors was $89.143 \%$, which can explain the majority of information in the raw data and reflect the pollution of heavy metal(loid)s. The first principal component (PC1) had strong positive loadings on As (0.811), $\mathrm{Cu}(0.964), \mathrm{Pb}(0.995)$, and $\mathrm{Zn}$ (0.992), and PC1 accounted for $42.750 \%$ of the total variance. Principal component 2 (PC2) was dominated by Cr, $\mathrm{Mn}, \mathrm{Ni}$, and $\mathrm{V}$ and explained $30.583 \%$ of the total variance. The loads of $\mathrm{Cr}, \mathrm{Ni}, \mathrm{Mn}$, and $\mathrm{V}$ on $\mathrm{PC} 2$ were $0.856,0.643,0.938$, and 0.705 , respectively. PC 3 explained only $15.809 \%$ of the total variance and showed strong loading primarily with Co (0.933). Figure S2 plots the PCA loadings for the three PCs, and it clearly indicated the association among the nine heavy metal(loid)s in the agricultural soils of the Shangdan Valley.

\subsubsection{Cluster Analysis Results}

CA is often used together with PCA to confirm the results in identifying the sources of heavy metal(loid) pollution. The dendrogram can directly reflect the distance and relationship between elements [58]. The clustering results are presented in Figure 3. It shows that the heavy metal(loid)s in the farmland soil in the Shangdan Valley could be classified into two groups: $\mathrm{Pb}-\mathrm{Zn}-\mathrm{Cu}-\mathrm{As}$ and $\mathrm{Cr}-\mathrm{Ni}-\mathrm{V}-\mathrm{Mn}-\mathrm{Co}$. In the second group, they can be further divided into $\mathrm{Cr}-\mathrm{Ni}-\mathrm{V}-\mathrm{Mn}$ and cobalt. The clustering results were consistent with the PCA results.

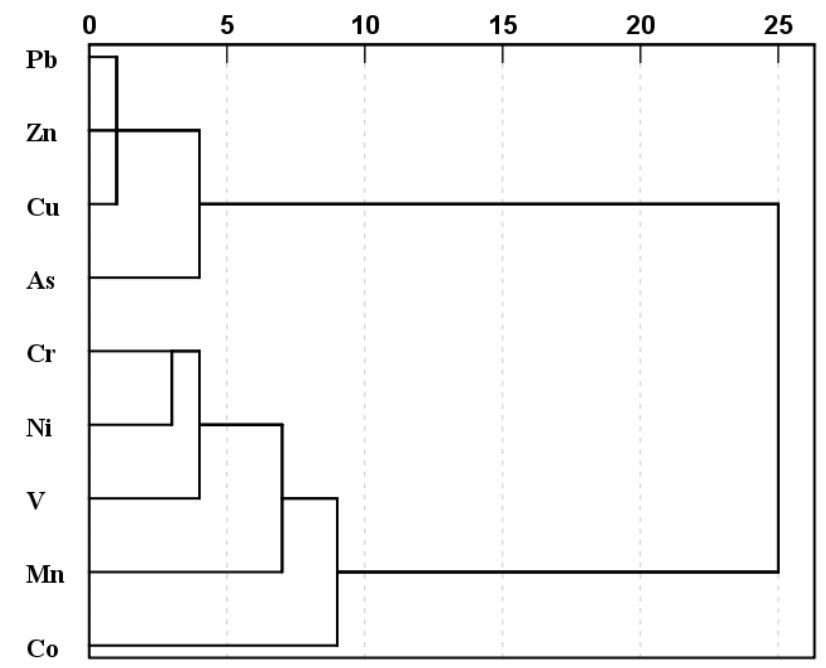

Figure 3. Dendrogram results from Ward's method of hierarchical cluster analysis for 9 elements. 


\subsection{Source Identification of Heavy Metal(loid)s}

Identification of sources of heavy metal(loid)s in farmland soil is the basis for taking appropriate measures to protect soil quality and developing sustainable management strategies [59-61]. The PCA result indicated that lead, zinc, copper, and arsenic were significantly correlated. In particular, the correlations among lead, zinc, copper, and arsenic were generally high, revealing the similar sources for these four elements [62,63]. Based on existing literature, the enrichment of $\mathrm{Zn}$ and $\mathrm{Pb}$ near the zinc smelter are enormously affected by the deposition of metal-containing dust $[64,65]$. In this study, the higher values of their spatial contents were in similar positions, all near a zinc-smelting plant, which was established in 1987, long before the establishment of the Shangdan Circular Industrial Economic Park. Zinc ore used in zinc smelter, sphalerite ( $\mathrm{ZnS})$, is one kind of sulfide mineral. Copper, $\mathrm{Pb}$, and As are the primarily associated elements of zinc ore. Combined with the content analysis, $\mathrm{Zn}, \mathrm{Cu}$, $\mathrm{Pb}$, and As had large coefficients of variation, and their contents in some samples were much higher than the reference values; hence PC1 can be better interpreted as an anthropogenic source related with zinc smelter. This interpretation can be further confirmed by the content characteristics of $\mathrm{S}$ and the correlation between $\mathrm{S}$ and $\mathrm{Zn}, \mathrm{Cu}, \mathrm{Pb}$, and $\mathrm{As}$. The higher contents of $\mathrm{S}$ were found in the soil samples collected around the zinc smelter. The significantly positive correlations $(p<0.01)$ were found in the element pairs of S- $\mathrm{Zn}(0.888), \mathrm{S}-\mathrm{Cu}(0.906), \mathrm{S}-\mathrm{Pb}(0.905)$, and S-As (0.626). In addition, Shangdan Valley has always been the major grain-producing area. Farm manure, pesticides, and phosphatic fertilizers are also important origins of $\mathrm{Cu}$ and As in agricultural soils [66-70]. Therefore it is reasonable to infer that the source of these elements is probably associated with metal smelting and agricultural activities.

Elements with close relationships usually mean that they have the same potential source [71]. Chromium, Mn, Ni, and V exhibited significantly positive correlations with each other in Pearson's correlation analysis. In the principal component analysis, they were classified into one group. Compared to other elements, the CVs of chromium, manganese, nickel, and vanadium were low, indicating a natural source affecting their spatial distribution. Past research has shown that the content of $\mathrm{Cr}$ and $\mathrm{Ni}$ in basic rock and ultrabasic rock is well above that of other parent materials [72,73], and chromium and nickel in the soil are mainly influenced by the parent material of soil formation $[24,74,75]$. For this reason, PC2 is primarily attributable to a natural source. Besides the loads on PC2, Mn had a load of 0.517 on PC1, which may suggest less significant anthropogenic origins. $\mathrm{V}$ had a load of 0.557 on PC3, which indicated that the source of V wasn't single. According to the above analysis, this group of elements can be interpreted as a natural source.

Co belongs to a class of its own in PCA and it is associated with a distinct source. In the cluster analysis, $\mathrm{Co}$ and $\mathrm{Cr}-\mathrm{Mn}-\mathrm{Ni}-\mathrm{V}$ groups are further separated. The $I_{\text {geo }}$ of $\mathrm{Co}$ was larger than that of $\mathrm{Cr}$, $\mathrm{Mn}, \mathrm{Ni}$, and $\mathrm{V}$ and reached a light pollution level, indicating that $\mathrm{Co}$ was enriched in agricultural soil. Although the coefficient of variation of Co was small, the $I_{\text {geo }}$ of Co reached the level of slightly polluted. It could be interrelated with human activities, such as combustion of fossil fuels and phosphate fertilizers application [76,77]. Based on Figure 3, Co is closer to the Cr-Ni-V-Mn group, indicating that $\mathrm{Co}$ originated partly from a natural source $[78,79]$. According to these results, Co in the agricultural soil was from a mixed source of nature, fossil fuel combustion, and fertilizer.

Once again, these results suggest that the contents of arsenic, copper, lead, and zinc in the agricultural soils of the Shangdan Valley were strongly influenced by anthropogenic activities, whereas chromium, manganese, nickel, and vanadium primarily originated from natural sources, and Co was mainly affected by a combination of natural and anthropogenic sources.

\section{Conclusions}

Heavy metal(loid)s ( $\mathrm{Cu}, \mathrm{Pb}, \mathrm{Zn}, \mathrm{Mn}, \mathrm{Ni}, \mathrm{V}, \mathrm{Co}, \mathrm{Cr}, \mathrm{As})$ accumulated to some extents in the agricultural soil of the Shangdan Valley. The average concentrations of $\mathrm{Zn}$ and $\mathrm{Pb}$ were 3.08 and 1.87 times the reference value, and the coefficients of variation were larger than $100 \%$, indicating that they were most significantly influenced by anthropogenic activities. $\mathrm{Mn}, \mathrm{Ni}, \mathrm{Cr}$, and As in the farmland 
soil of the Shangdan Valley were in an unpolluted state, and $\mathrm{Zn}, \mathrm{Co}, \mathrm{Cu}, \mathrm{V}$, and $\mathrm{Pb}$ were in a slightly polluted state on the whole. However, element $\mathrm{Zn}$ in some sample points near the zinc smelter reached a moderately polluted level or even severely extremely polluted level, and the point source pollution characteristics were obvious. The overall pollution of the heavy metal(loid)s in the farmland soil was moderate on the whole, except for in a few samples where it was serious. All investigated heavy metal(loid)s had low ecological risk in the agricultural soil, while their total ecological risks were low to moderate.

The investigated heavy metal(loid)s in the agricultural soil of the Shangdan Valley primarily came from three sources. Arsenic, copper, lead, and zinc were mainly controlled by metal smelting and agricultural activities. Chromium, manganese, nickel, and vanadium were mainly affected by rock weathering and soil-forming parent material, while Co was from a mixed source of nature, fossil fuel combustion, and fertilizer. It should be noted that the pollution degree and ecological risk of heavy metal(loid)s in the farmland soil around metal smelting plants were severe. Therefore, the monitoring and measuring of industrial emission should be strengthened hereafter.

Supplementary Materials: The following are available online at http://www.mdpi.com/2071-1050/12/14/5806/s1, Figure S1: Location of the Shangdan Basin and sampling sites. Figure S2: 3D plot of PCA loadings for nine heavy metal(loid)s. Table S1: Standard classification of the Nemerow comprehensive pollution index for soil. Table S2: Grade of $I_{\text {geo }}$. Table S3 Grade standards for $E_{r}{ }^{i}$ and PERI. Table S4: $P_{i}$ and NSPI of heavy metal(loid)s in the agricultural soil of the Shangdan Valley. Table S5: Index of geo-accumulation ( $\left.I_{g e o}\right)$ of heavy metal(loid)s in the agricultural soil in the Shangdan Valley. Table S6: $E_{r}{ }^{i}$ and $R I$ of heavy metal(loid)s in the agricultural soil in the Shangdan Valley.

Author Contributions: Conceptualization, S.Z. and X.L.; methodology, S.Z. and X.L.; software, S.Z.; validation, S.Z. and X.L.; formal analysis, S.Z.; investigation, S.Z.; resources, S.Z.; data curation, S.Z.; writing—original draft preparation, S.Z.; writing-review and editing, X.L.; visualization, S.Z.; supervision, X.L.; project administration, S.Z.; funding acquisition, X.L. All authors have read and agreed to the published version of the manuscript.

Funding: This research was funded by the National Natural Science Foundation of China, grant number 41271510, the Research and Development Key Project of Shaanxi Province, grant number 2020SF-433, Shaanxi Province Natural Science Foundation Research Project, grant number 2014JM2-4040, and Science and Technology Research Project of Shangluo University, grant number SK2014-01-24.

Acknowledgments: We thank the staff of the Environmental Science Laboratory, Shaanxi Normal University, for their help with the laboratory work.

Conflicts of Interest: The authors declare no conflict of interest.

\section{References}

1. Wang, S.; Cai, L.; Wen, H.; Luo, J.; Wang, Q.; Liu, X. Spatial distribution and source apportionment of heavy metals in soil from a typical county-level city of Guangdong Province, China. Sci. Total Environ. 2019, 655, 92-101. [CrossRef]

2. Fei, X.; Xiao, R.; Christakos, G.; Langousis, A.; Ren, Z.; Tian, Y.; Lv, X. Comprehensive assessment and source apportionment of heavy metals in Shanghai agricultural soils with different fertility levels. Ecol. Indic. 2019, 106, 105508. [CrossRef]

3. Marrugo-Negrete, J.; Pinedo-Hernández, J; Díez, S. Assessment of heavy metal pollution, spatial distribution and origin in agricultural soils along the Sinú River Basin, Colombia. Environ. Res. 2017, 154, 380-388. [CrossRef] [PubMed]

4. Hu, Y.; He, K.; Sun, Z.; Chen, G.; Cheng, H. Quantitative source apportionment of heavy metal(loid)s in the agricultural soils of an industrializing region and associated model uncertainty. J. Hazard. Mater. 2020, $391,122244$.

5. Burges, A.; Epelde, L.; Garbisu, C. Impact of repeated single-metal and multi-metal pollution events on soil quality. Chemosphere 2015, 120, 8-15. [CrossRef] [PubMed]

6. Mazurek, R.; Kowalska, J.; Gasiorek, M.; Zadrożny, P.; Józefowska, A.; Zaleski, T.; Kępka, W.; Tymczuk, M.; Orłowska, K. Assessment of heavy metals contamination in surface layers of Roztocze National Park forest soils (SE Poland) by indices of pollution. Chemosphere 2017, 168, 839-850. [CrossRef] 
7. Skowrońska, M.; Bielińska, E.J.; Szymański, K.; Futa, B.; Antonkiewicz, J.; Kołodziej, B. An integrated assessment of the long-term impact of municipal sewage sludge on the chemical and biological properties of soil. Catena 2020, 189, 104484. [CrossRef]

8. Guan, Q.; Wang, F.; Xu, C.; Pan, N.; Lin, J.; Zhao, R.; Yang, Y.; Luo, H. Source apportionment of heavy metals in agricultural soil based on PMF: A case study in Hexi Corridor, northwest China. Chemosphere 2018, 193, 189-197. [CrossRef]

9. Chen, H.; Lu, X.; Li, L.Y.; Gao, T.; Chang, Y. Metal contamination in campus dust of Xi'an, China: A study based on multivariate statistics and spatial distribution. Sci. Total Environ. 2014, 484, 27-35. [CrossRef]

10. Doabi, S.A.; Karami, M.; Afyuni, M.; Yeganeh, M. Pollution and health risk assessment of heavy metals in agricultural soil, atmospheric dust and major food crops in Kermanshah province, Iran. Ecotoxicol. Environ. Saf. 2018, 163, 153-164. [CrossRef]

11. Jiang, H.; Cai, L.; Wen, H.; Hu, G.; Chen, L.; Luo, J. An integrated approach to quantifying ecological and human health risks from different sources of soil heavy metals. Sci. Total Environ. 2020, 701, 134466. [CrossRef] [PubMed]

12. He, M.; Shen, H.; Li, Z.; Wang, L.; Wang, F.; Zhao, K.; Liu, X.; Wendroth, O.; Xu, J. Ten-year regional monitoring of soil-rice grain contamination by heavy metals with implications for target remediation and food safety. Environ. Pollut. 2019, 244, 431-439. [CrossRef] [PubMed]

13. Jin, G.; Fang, W.; Shafi, M.; Wu, D.; Li, Y.; Zhong, B.; Ma, J.; Liu, D. Source apportionment of heavy metals in farmland soil with application of APCS-MLR model: A pilot study for restoration of farmland in Shaoxing City Zhejiang, China. Ecotoxicol. Environ. Saf. 2019, 184, 109495. [CrossRef] [PubMed]

14. Yang, S.; Zhao, J.; Chang, S.X.; Collins, C.; Xu, J.; Liu, X. Status assessment and probabilistic health risk modeling of metals accumulation in agriculture soils across China: A synthesis. Environ. Int. 2019, 128, 165-174. [CrossRef] [PubMed]

15. Wu, W.; Wu, P.; Yang, F.; Sun, D.; Zhang, D.; Zhou, Y. Assessment of heavy metal pollution and human health risks in urban soils around an electronics manufacturing facility. Sci. Total Environ. 2018, 630, 53-61. [CrossRef] [PubMed]

16. Xue, S.; Shi, L.; Wu, C.; Wu, H.; Qin, Y.; Pan, W.; Hartley, W.; Cui, M. Cadmium, lead, and arsenic contamination in paddy soils of a mining area and their exposure effects on human HEPG2 and keratinocyte cell-lines. Environ. Res. 2017, 156, 23-30. [CrossRef] [PubMed]

17. Zhang, J.; Wang, L.; Yang, J.; Liu, H.; Dai, J. Health risk to residents and stimulation to inherent bacteria of various heavy metals in soil. Sci. Total Environ. 2015, 508, 29-36. [CrossRef]

18. Adimalla, N.; Chen, J.; Qian, H. Spatial characteristics of heavy metal contamination and potential human health risk assessment of urban soils: A case study from an urban region of South India. Ecotoxicol. Environ. Saf. 2020, 194, 110406. [CrossRef]

19. Timofeev, I.; Kosheleva, N.; Kasimov, N. Health risk assessment based on the contents of potentially toxic elements in urban soils of Darkhan, Mongolia. J. Environ. Manage. 2019, 242, 279-289. [CrossRef]

20. Fazekašová, D.; Fazekaš, J. Soil quality and heavy metal pollution assessment of Iron ore mines in Nizna Slana (Slovakia). Sustainability 2020, 12, 2549. [CrossRef]

21. Wang, D.; Xu, Q.; Zheng, Q.; Wu, L. Assessment of the health effects of heavy metals pollution of agricultural soils in the iron ore mining area of the northern piedmont of mountain Wutai Shaanxi province, China. Sustainability 2020, 12, 1926. [CrossRef]

22. Yan, D.; Bai, Z.; Liu, X. Heavy-metal pollution characteristics and influencing factors in agricultural soils: Evidence from Shuozhou city, Shanxi province, China. Sustainability 2020, 12, 1907. [CrossRef]

23. Zhang, S.; Liu, Y.; Ni, X.; Arif, M.; Charles, W.; Li, C. Trace elements in soils of a typical industrial district in Ningxia, northwest China: Pollution, source, and risk evaluation. Sustainability 2020, 12, 1868. [CrossRef]

24. Wang, F.; Guan, Q.; Tian, J.; Lin, J.; Yang, Y.; Yang, L.; Pan, N. Contamination characteristics, source apportionment, and health risk assessment of heavy metals in agricultural soil in the Hexi Corridor. Catena 2020, 191, 104573. [CrossRef]

25. Zeng, S.; Ma, J.; Yang, Y.; Zhang, S.; Liu, G.; Chen, F. Spatial assessment of farmland soil pollution and its potential human health risks in China. Sci. Total Environ. 2019, 687, 642-653. [CrossRef]

26. Cai, L.; Wang, Q.; Wen, H.; Luo, J.; Wang, S. Heavy metals in agricultural soils from a typical township in Guangdong Province, China: Occurrences and spatial distribution. Ecotoxicol. Environ. Saf. 2019, 168, 184-191. [CrossRef] [PubMed] 
27. Liu, G.; Shi, Y.; Guo, G.; Zhao, L.; Niu, J.; Zhang, C. Soil pollution characteristics and systemic environmental risk assessment of a large-scale arsenic slag contaminated site. J. Clean. Prod. 2020, 251, 119721. [CrossRef]

28. Shi, T.; Ma, J.; Wu, F.; Ju, T.; Gong, Y.; Zhang, Y.; Wu, X.; Hou, H.; Zhao, L.; Shi, H. Mass balance-based inventory of heavy metals inputs to and outputs from agricultural soils in Zhejiang Province, China. Sci. Total Environ. 2019, 649, 1269-1280. [CrossRef]

29. Ni, M.; Mao, R.; Jia, Z.; Dong, R.; Li, S. Heavy metals in soils of Hechuan County in the upper Yangtze (SW China): Comparative pollution assessment using multiple indices with high-spatial resolution sampling. Ecotoxicol. Environ. Saf. 2018, 148, 644-651. [CrossRef]

30. Sun, L.; Guo, D.; Liu, K.; Meng, H.; Zheng, Y.; Yuan, F.; Zhu, G. Levels, sources, and spatial distribution of heavy metals in soils from a typical coal industrial city of Tangshan, China. Catena 2019, 175, 101-109. [CrossRef]

31. Varol, M.; Sünbül, M.R.; Aytop, H.; Yılmaz, C.H. Environmental, ecological and health risks of trace elements, and their sources in soils of Harran Plain, Turkey. Chemosphere 2020, 245, 125592. [CrossRef] [PubMed]

32. Wu, C.; Shi, L.; Xue, S.; Li, W.; Jiang, X.; Rajendran, M.; Qian, Z. Effect of sulfur-iron modified biochar on the available cadmium and bacterial community structure in contaminated soils. Sci. Total Environ. 2019, 647, 1158-1168. [CrossRef] [PubMed]

33. Xia, Y.; Luo, H.; Li, D.; Chen, Z.; Yang, S.; Liu, Z.; Yang, T.; Gai, C. Efficient immobilization of toxic heavy metals in multi-contaminated agricultural soils by amino-functionalized hydrochar: Performance, plant responses and immobilization mechanisms. Environ. Pollut. 2020, 261, 114217. [CrossRef] [PubMed]

34. Lu, X.; Zhang, X.; Li, L.Y.; Chen, H. Assessment of metals pollution and health risk in dust from nursery schools in Xi'an, China. Environ. Res. 2014, 128, 27-34. [CrossRef] [PubMed]

35. Chen, H.; Lu, X.; Li, L.Y. Spatial distribution and risk assessment of metals in dust based on samples from nursery and primary schools of Xi'an, China. Atmos. Environ. 2014, 88, 172-182. [CrossRef]

36. Shi, D.; Lu, X. Accumulation degree and source apportionment of trace metals in smaller than $63 \mu \mathrm{m}$ road dust from the areas with different land uses: A case study of Xi'an, China. Sci. Total Environ. 2018, 636, 1211-1218. [CrossRef] [PubMed]

37. Chen, T.; Zheng, Y.; Lei, M.; Huang, Z.; Wu, H.; Chen, H.; Fan, K.; Yu, K.; Wu, X.; Tian, Q. Assessment of heavy metal pollution in surface soils of urban parks in Beijing, China. Chemosphere 2005, 60, 542-551. [CrossRef]

38. Lu, X.; Wang, L.; Lei, K.; Huang, J.; Zhai, Y. Contamination assessment of copper, lead, zinc, manganese and nickel in street dust of Baoji, NW China. J. Hazard. Mater. 2009, 161, 1058-1062. [CrossRef]

39. CNEMC (China National Environmental Monitoring Centre). The Background Values of Elements in Chinses Soils; Environmental Science Press of China: Beijing, China, 1990.

40. Chen, H.; Lu, X.; Chang, Y.; Xue, W. Heavy metal contamination in dust from kindergartens and elementary schools in Xi'an, China. Environ. Earth Sci. 2014, 71, 2701-2709. [CrossRef]

41. Lu, X.; Pan, H.; Wang, Y. Pollution evaluation and source analysis of heavy metal in roadway dust from a resource-typed industrial city in Northwest China. Atmos. Pollut. Res. 2017, 8, 587-595. [CrossRef]

42. Müller, G. Index of geo accumulation in sediments of the Rhine River. Geol. J. 1969, 2, 108-118.

43. Zhang, Z.; Lu, Y.; Li, H.; Tu, Y.; Liu, B.; Yang, Z. Assessment of heavy metal contamination, distribution and source identification in the sediments from the Zijiang River, China. Sci. Total Environ. 2018, 645, 235-243. [CrossRef] [PubMed]

44. Zhang, P.; Qin, C.; Hong, X.; Kang, G.; Qin, M.; Yang, D.; Pang, B.; Li, Y.; He, J.; Dick, R.P. Risk assessment and source analysis of soil heavy metal pollution from lower reaches of Yellow River irrigation in China. Sci. Total Environ. 2018, 633, 1136-1147. [CrossRef]

45. Lu, X.; Li, L.Y.; Wang, L.; Lei, K.; Huang, J.; Zhai, Y. Contamination assessment of mercury and arsenic in roadway dust from Baoji, China. Atmos. Environ. 2009, 43, 2489-2496. [CrossRef]

46. Pan, H.; Lu, X.; Lei, K. Lead in roadway dusts from different functional areas in a typical valley city, NW China: Contamination and exposure risk. Environ. Sci. Pollut. Res. 2018, 25, 523-532. [CrossRef]

47. Hakånson, L. An Ecological Risk Index for Aquatic Pollution Control-A Sedimentological Approach. Water Res. 1980, 14, 975-1001. [CrossRef]

48. Ke, X.; Gui, S.; Huang, H.; Zhang, H.; Wang, C.; Guo, W. Ecological risk assessment and source identification for heavy metals in surface sediment from the Liaohe River protected area, China. Chemosphere 2017, 175, 473-481. [CrossRef] 
49. Kusin, F.M.; Azani, N.N.M.; Hasan, S.N.M.S.; Sulong, N.A. Distribution of heavy metals and metalloid in surface sediments of heavily-mined area for bauxite ore in Pengerang, Malaysia and associated risk assessment. Catena 2018, 165, 454-464. [CrossRef]

50. Yuan, G.; Sun, T.; Han, P.; Li, J.; Lang, X. Source identification and ecological risk assessment of heavy metals in topsoil using environmental geochemical mapping: Typical urban renewal area in Beijing, China. J. Geochem. Explor. 2014, 136, 40-47. [CrossRef]

51. Lu, X.; Shi, D.; Yin, N.; Pan, H.; Smith, P. Risk assessment of heavy metals in finer than 63- $\mu$ mdust particles from various functional areas in Xi'an, China. Air Qual. Atmos. Health 2017, 10, 907-915. [CrossRef]

52. Lu, X.; Wu, X.; Wang, Y.; Chen, H.; Gao, P.; Fu, Y. Risk assessment of toxic metals in street dust from a medium-sized industrial city of China. Ecotoxicol. Environ. Saf. 2014, 106, 154-163. [CrossRef] [PubMed]

53. Cheng, H.; Li, K.; Li, M.; Yang, K.; Liu, F.; Cheng, X. Geochemical background and base line value of chemical elements in urban soil in China. Earth Sci. Front. 2014, 21, 265-306.

54. Chen, X.; Lu, X.; Yang, G. Sources identification of heavy metals in urban topsoil from inside the Xi'an Second Ringroad, NW China using multivariate statistical methods. Catena 2012, 98, 73-78. [CrossRef]

55. Lu, X.; Wang, L.; Li, L.Y.; Lei, K.; Huang, L.; Kang, D. Multivariate statistical analysis of heavy metals in street dust of Baoji, NW China. J. Hazard. Mater. 2010, 173, 744-749. [CrossRef] [PubMed]

56. Dong, B.; Zhang, R.; Gan, Y.; Cai, L.; Freidenreich, A.; Wang, K.; Guo, T.; Wang, H. Multiple methods for the identification of heavy metal sources in cropland soils from a resource-based region. Sci. Total Environ. 2019, 651, 3127-3138. [CrossRef] [PubMed]

57. Wang, Q.; Lu, X.; Pan, H. Analysis of heavy metals in the re-suspended road dusts from different functional areas in Xi'an, China. Environ. Sci. Pollut. Res. 2016, 23, 19838-19846. [CrossRef]

58. Pan, L.; Ma, J.; Wang, X.; Hou, H. Heavy metals in soils from a typical county in Shanxi Province, China: Levels, sources and spatial distribution. Chemosphere 2016, 148, 248-254. [CrossRef]

59. Hu, W.; Wang, H.; Dong, L.; Huang, B.; Borggaard, O.K.; Hansen, H.C.B.; He, Y.; Holm, P.E. Source identification of heavy metals in peri-urban agricultural soils of southeast China: An integrated approach. Environ. Pollut. 2018, 237, 650-661. [CrossRef]

60. Li, S.; Jia, Z. Heavy metals in soils from a representative rapidly developing megacity (SW China): Levels, source identification and apportionment. Catena 2018, 163, 414-423. [CrossRef]

61. Wu, J.; Li, J.; Teng, Y.; Chen, H.; Wang, Y. A partition computing-based positive matrix factorization (PC-PMF) approach for the source apportionment of agricultural soil heavy metal contents and associated health risks. J. Hazard. Mater. 2020, 388, 121766. [CrossRef]

62. Chabukdhara, M.; Nema, A.K. Heavy metals assessment in urban soil around industrial clusters in Ghaziabad, India: Probabilistic health risk approach. Ecotoxicol. Environ. Saf. 2013, 87, 57-64. [CrossRef] [PubMed]

63. Yang, Z.; Lu, W.; Long, Y.; Bao, X.; Yang, Q. Assessment of heavy metals contamination in urban topsoil from Changchun City, China. J. Geochem. Explor. 2011, 108, 27-38. [CrossRef]

64. Shen, F.; Liao, R.; Ali, A.; Mahar, A.; Guo, D.; Li, R.; Sun, X.; Awasthi, M.K.; Wang, Q.; Zhang, Z. Spatial distribution and risk assessment of heavy metals in soil near a $\mathrm{Pb} / \mathrm{Zn}$ smelter in Feng County, China. Ecotoxicol. Environ. Saf. 2017, 139, 254-262. [CrossRef] [PubMed]

65. Zhang, X.; Wei, S.; Sun, Q.; Wadood, S.A.; Guo, B. Source identification and spatial distribution of arsenic and heavy metals in agricultural soil around Hunan industrial estate by positive matrix factorization model, principle components analysis and geo statistical analysis. Ecotoxicol. Environ. Saf. 2018, 159, 354-362. [CrossRef]

66. Franco-Uría, A.; López-Mateo, C.; Roca, E.; Fernández-Marcos, M.L. Source identification of heavy metals in pastureland by multivariate analysis in NW Spain. J. Hazard. Mater. 2009, 165, 1008-1015. [CrossRef]

67. Hani, A.; Pazira, E. Heavy metals assessment and identification of their sources in agricultural soils of Southern Tehran, Iran. Environ. Monit. Assess. 2011, 176, 677-691. [CrossRef]

68. Micó, C.; Recatalá, L.; Peris, M.; Sánchez, J. Assessing heavy metal sources in agricultural soils of an European Mediterranean area by multivariate analysis. Chemosphere 2006, 65, 863-872. [CrossRef]

69. Wang, L.; Gao, S.; Yin, X.; Yu, X.; Luan, L. Arsenic accumulation, distribution and source analysis of rice in a typical growing area in north China. Ecotoxicol. Environ. Saf. 2019, 167, 429-434. [CrossRef]

70. Xiao, R.; Guo, D.; Ali, A.; Mi, S.; Liu, T.; Ren, C.; Li, R.; Zhang, Z. Accumulation, ecological-health risks assessment, and source apportionment of heavy metals in paddy soils: A case study in Hanzhong, Shaanxi, China. Environ. Pollut. 2019, 248, 349-357. [CrossRef] 
71. Dartan, G.; Taspinar, F.; Toroz, I. Assessment of heavy metals in agricultural soils and their source apportionment: A Turkish district survey. Environ. Monit. Assess. 2015, 187, 99. [CrossRef]

72. Baltas, H.; Sirin, M.; Gökbayrak, E.; Ozcelik, A.E. A case study on pollution and a human health risk assessment of heavy metals in agricultural soils around Sinop province, Turkey. Chemosphere 2020, 241, 125015. [CrossRef] [PubMed]

73. Liang, J.; Feng, C.; Zeng, G.; Gao, X.; Zhong, M.; Li, X.; Li, X.; He, X.; Fang, Y. Spatial distribution and source identification of heavy metals in surface soils in a typical coal mine city, Lianyuan, China. Environ. Pollut. 2017, 225, 681-690. [CrossRef]

74. Lv, J. Multivariate receptor models and robust geostatistics to estimate source apportionment of heavy metals in soils. Environ. Pollut. 2019, 244, 72-83. [CrossRef] [PubMed]

75. Sun, C.; Liu, J.; Wang, Y.; Sun, L.; Yu, H. Multivariate and geostatistical analyses of the spatial distribution and sources of heavy metals in agricultural soil in Dehui, Northeast China. Chemosphere 2013, 92, 517-523. [CrossRef] [PubMed]

76. Linhares, D.; Pimentel, A.; Borges, C.; Cruz, J.V.; Garcia, P.; Rodrigues, A.S. Cobalt distribution in the soils of São Miguel Island (Azores): From volcanoes to health effects. Sci. Total Environ. 2019, 684, 715-721. [CrossRef]

77. Pathak, A.K.; Kumar, R.; Kumar, P.; Yadav, S. Sources apportionment and spatio-temporal changes in metal pollution in surface and sub-surface soils of a mixed type industrial area in India. J. Geochem. Explor. 2015, 159, 169-177. [CrossRef]

78. Facchinelli, A.; Sacchi, E.; Mallen, L. Multivariate statistical and GIS-based approach to identify heavy metal sources in soils. Environ. Pollut. 2001, 114, 313-324. [CrossRef]

79. Pan, H.; Lu, X.; Lei, K. A comprehensive analysis of heavy metals in urban road dust of Xi'an, China: Contamination, source apportionment and spatial distribution. Sci. Total Environ. 2017, 609, 1361-1369. [CrossRef]

(C) 2020 by the authors. Licensee MDPI, Basel, Switzerland. This article is an open access article distributed under the terms and conditions of the Creative Commons Attribution (CC BY) license (http://creativecommons.org/licenses/by/4.0/). 